\title{
The Continuing Relevance of "Queer" Theology for the Rest of the Field
}

\author{
Colby Dickinson \\ Loyola University Chicago, cdickinson1@luc.edu \\ Meghan Toomey \\ Loyola University Chicago
}

Follow this and additional works at: https://ecommons.luc.edu/theology_facpubs

Part of the Feminist, Gender, and Sexuality Studies Commons, and the Religious Thought, Theology and Philosophy of Religion Commons

Author Manuscript

This is a pre-publication author manuscript of the final, published article.

\section{Recommended Citation}

Dickinson, Colby and Toomey, Meghan. The Continuing Relevance of "Queer" Theology for the Rest of the Field. Theology \& Sexuality, 23, 1-2: 1-16, 2017. Retrieved from Loyola eCommons, Theology: Faculty Publications and Other Works, http://dx.doi.org/10.1080/13558358.2017.1341210

This Article is brought to you for free and open access by the Faculty Publications and Other Works by Department at Loyola eCommons. It has been accepted for inclusion in Theology: Faculty Publications and Other Works by an authorized administrator of Loyola eCommons. For more information, please contact ecommons@luc.edu. c) (i) $\Theta$

This work is licensed under a Creative Commons Attribution-Noncommercial-No Derivative Works 3.0 License. (c) Taylor \& Francis 2017 


\title{
The Continuing Relevance of 'Queer' Theology for the Rest of the Field
}

\author{
Colby Dickinson and Meghan Toomey
}

\section{Introduction}

Over the past 30 years, queer theology has grown exponentially, and this trend shows little sign of tapering off in the near future. For the most part, however, queer theologians have remained marginalized within mainstream academic theological discourse. Thus, for many, the place of queer theology has become yet another variety of a 'disembodied' contextual theology. Nonetheless, this does not displace the continued relevance that inquiries in queer theology, and into the queerness of theology itself, have within academic discourse on a larger scale. Therefore, when we consider what direction a queer theology should take, we should not forget the importance of gaining the attention of those within mainstream theology, as it may be they who will benefit most from an engaged and sustained dialogue with queerness.

Many might anticipate that a discussion about the future direction of queer theology would be primarily concerned with establishing for itself a more 'normative' place in mainstream theological inquiry. Perhaps a logical starting place for such a project would be building a foundation upon which to argue that sexual diversity is 'normal', offering (re)readings of the bible that legitimate homosexual identities, varying expressions of sexuality, and so forth. Although such projects are certainly necessary and worthwhile, we do not think that queer theology should be founded upon such inquiries. In fact, we understand these questions to be secondary, and, in a certain sense, irrelevant in some sense because they belong to a category of questions that truly has little impact on the 'real' issues lurking behind our inquiry, and toward which we must orient ourselves more directly.

From our perspective, a queer theology — whatever shape it is to take going forward — should be particularly attentive to the ways in which we determine Christian or religious identity in relation to structures of oppression, especially those within churches and mainstream theology. To do so, we must honestly ask ourselves who it is today that has unique insight into the conditions of living on the margins. Who is it among us that is truly attuned to an existence of 'non-normative' status, in which their very bodies bear the condition of marginality, especially as such an existence demands discarding longestablished preconceived notions about social and bodily relations. We assert that queer theology has a responsibility to such forms of existence. This responsibility demands that we offer insights which contain the potential to actually assist Christians in embracing the 'narrow path' that leads to their own salvation - whatever such a path may or may not be.

With precisely these tasks in mind, this edited collection of essays intends to present a diversity of discussions on the relevance of queer theology that specifically avoids centering on biblical (re)interpretations and biological normativity, opting instead to focus on epistemological questions about the normativity of theological models and methods. For example, in her contribution to this volume, Wendy Farley argues that using an apophatic approach can mediate 'patterns of thought and authoritarian patterns' that have been essentialized within ecclesial structures, such as the ongoing influence of understanding gender and sexuality as concepts containing binary oppositions (man/woman and homo/hetero-sexuality). ${ }^{1}$ Farley explains in her essay how these (false) objectifications distort reality (perceived and lived) and demean the identity of those who inhabit a 'rugged landscape' at the 'margins of an ecclesial institution whose rhetoric and practices have consistently debased our [queer] identity.'

\footnotetext{
${ }^{1}$ Farley, Wendy. “'Never Known as Anything but an Absence, I Dare Not Name Him as God:' Queer Theology and the Via Negativa" in Queerying Theology's Object edited by Colby Dickinson, Aimee Light, Kent Britnall, and Meghan Toomey, [insert page number/s]. Abingdon: Taylor \& Francis, [insert publication year].

2 Ibid.
} 
Speaking from her own queer perspective, Farley argues that ecclesial powers 'conspire to defraud us of life-giving awareness of the profound beauty of divine and human reality.' ${ }^{3}$

Farley's essay touches on an important focus for this volume in general. This collection examines how the queering of theology, whatever such a movement is or can be, poses a challenge to traditional and ecclesial frameworks and knowledges, as well as expose fundamental tensions within the lengthy history of theological inquiry. The essays herein challenge us to reconsider not only what is meant by 'normative' and 'orthodox' from a Christian perspective, but also, how such determinations come about. Indeed, the ultimate usefulness of such methodology in a postmodern world is directly in question: can structures of normativity or standards of orthodoxy even survive such a queer critique - more importantly, should they survive?

Essays within this volume attempt to answer questions such as these by critically examining the relationship between queer theology and mainstream Christian theological norms. This volume also seeks to identify what role queer theology plays in reference to these norms, and makes suggestions about what this role should look like in the future. Susannah Cornwall commences her chapter, entitled 'Home and Hiddenness: Queer Theology, Domestication and Institutions', with the following quote from Marcella Althaus-Reid and Lisa Isherwood (who themselves have contributed groundbreaking work to queer theological thought):

Queer Theology takes its place not at the centre of the theological discourses conversing with power, but at the margins. It is a theology from the margins that wants to remain at the margins. To recognize sexual discrimination in the church and in theological thinking... does not mean that a theology from the margins should strive for equality. Terrible is the fate of theologies from the margin when they want to be accepted by the centre! ${ }^{4}$

Cornwall uses this quote to ground her investigation into the 'increasing mainstreaming of queer theologies in institutional (e.g. university, seminary, church) settings, and the inclusion of queer theologies by straight academics and teachers on their syllabi. ${ }^{5}$ Cornwall also encourages queer theologians to resist the domestication and institutionalization of Queer Theology, lest there be no place left for "'shadow queernesses' which reject institutional acceptability."

Our conception of the queering of theology shares Cornwall's concern. Queer theology's aim has been (and should continue to be) to decenter the 'standard' patterns of theological talk, not to centralize itself within this dialogue. One way it accomplishes this is by continually shifting focus onto the real persons and lives that exist at the margins of both society and Christianity. Kent Brintnall's essay in this volume achieves this by bringing together differing voices from the recent 'cultural wars' surrounding LGBT civil rights, and by using contemporary representations of culture as expressed in film and newsprint to elucidate his points. Drawing from the central themes presented in the groundbreaking HBO film Angels in America: A Gay Fantasia of National Themes, Brintnall establishes movement as the essence of human life itself. Human beings are radically in flux, he explains, 'They are movement; they are life and want more life. Radical flux is not a problem to be solved; it is a resource to be exploited. ${ }^{7}$ Like Farley,

\footnotetext{
3 Ibid.

${ }^{4}$ Althaus-Reid, Marcella and Lisa Isherwood (2007), 'Thinking Theology and Queer Theory', Feminist Theology $15.3,304$.

${ }^{5}$ Cornwall, "Home and Hiddenness: Queer Theology, Domestication and Institutions" in Queerying Theology's Object edited by Colby Dickinson, Aimee Light, Kent Britnall, and Meghan Toomey, [insert page number/s]. ${ }^{6}$ Ibid.

${ }^{7}$ Brintnall, Kent. "Desire's Revelatory Conflagration” in Queerying Theology's Object edited by Colby Dickinson, Aimee Light, Kent Britnall, and Meghan Toomey, [insert page number/s].
} 
Brintnall emphasizes queer theology's apophatic antecedents in his meditation of this movement, calling into question the authenticity of labeling the movement in a normative way with the titling of 'queer theology', something that may actually, if genuinely deployed, resist such a label. Several other contributors to this volume also highlight different ways in which apophatic approaches are closely connected to queer theory in its thinking 'by way of denial', or via negative. ${ }^{8}$

There is no doubt that trying to contextualize something like a queer theology today means recognizing how it springs forth from the depths of other theological approaches, especially ones that have shared the desire to 'free' theology from the various confinements of mainstream representations and practices. ${ }^{9}$ In this sense, queer theology joins in the noble tradition of those that seek to disrupt the field of theology, moving through its structures and institutions as a disorderly force in order to contest its narratives of selflegitimization. Thus, queer theology draws especially on its lineage with contextual theologies and theologies of liberation.

The most explicit connection to liberation theologies presented in this volume is found in Allyson Dean and Whitney Archer's essay, 'Transgressing the Father Figure: Performing Queer Theology as an Act of Liberation', in which they outline their vision of a queer doing of theology. Focusing on drag performance as a 'medium for engaging in theological discourse', Dean and Archer 'suggest the possibility of liberation that exists in bringing theology into queer spaces, extending theology beyond the realm of religious institutions or the academy. ${ }^{10}$ Similar to Farley, Dean and Archer take their cue from Althaus-Reid and Isherwood, investigating the possibilities of 'unlearning' theologies and sexualities that are oppressive and homophobic. ${ }^{11}$ They offer a 'theology of performance', as an effective tool for such subversion of norms, affirming that drag performance is liberating to queer bodies, minds and spirits. ${ }^{12}$

In our view, doing queer theology, or queering theology itself, contains a demand both for good academic theology and for authentic Christian discipleship. As such, the task of queer theology, whatever such a thing is or is not, admits the priority of genuine humility in its theological inquiry. We should begin by asking: what have we to learn from the 'non-normative' world that is 'queer' living, and how can we be in critical dialogue with these groups and persons? We would like then to see a series of questions arise which not only offer themselves as critiques of traditional normative religious scripts, but also as potential paths toward the liberation of all believers. Queer theology, from the outset, needs to investigate what forms of non-normative love, touch, marriage and sex effectively challenge patriarchal power, and how such non-normative forms can assist in the remodeling of 'normative' relationships. Genuinely queering theology also demands that those of us who belong to historically normative groups consider what we are being called to do, think and believe by these traditionally non-normative forms of love, touch, marriage and sex.

In what follows, we will provide a brief history of queer theology, tracing its development from some of its early origins in the late $20^{\text {th }}$ Century to today. Out of this overview, we will highlight four themes that we consider essential to the study of queer theology as a whole: 1) the role of witness, 2) the project of disentangling the 'real' issues from the incidentals in reactions to a queer presence in the Church, 3) the

\footnotetext{
${ }^{8}$ In addition to Brintnall and Farley, Jay Emerson Johnson, Brandy Daniels and Kristien Justaert all mention apophatic approaches in their essays in this volume.

${ }^{9}$ The reference here is to Catherine Mowry LaCugna, ed., Freeing Theology: The Essentials of Theology in Feminist Perspective (New York: HarperCollins, 1993).

${ }^{10}$ Dean and Archer, "Transgressing the Father Figure: Performing Queer Theology as an Act of Liberation" in Queerying Theology's Object edited by Colby Dickinson, Aimee Light, Kent Britnall, and Meghan Toomey, [insert page number/s].

${ }^{11}$ Ibid., 2; the reference made to Althaus-Reid and Isherwood is from 'Thinking Theology and Queer Theory', Feminist Theology 15.3, 307.

${ }^{12}$ Ibid., 14.
} 
creative rereading of tradition with an eye toward emancipation and, 4) the ways in which queer theology orients the field of theological studies as a whole to what really matters (or ought to matter) for Christians and others seeking to follow the witness of Jesus.

\section{A Selective History of Queer Theology}

One of the first sustained engagements with what we might call an early form of queer theology, Robert Goss' Jesus Acted Up: A Gay and Lesbian Manifesto (1993), took feminist liberation theological methodologies and applied them to LGBT persons. In Jesus Acted Up, Goss imagines a 'queer Christ' in order to demonstrate how Jesus himself went to the margins of society and took account of the knowledges found there. Goss emphasizes how such knowledges found at the margins might better inform us of who we are as sexual human beings. Four years later, Gary David Comstock and Susan E. Henking published Que(e)rying Religion (1997), a book whose scope was not limited to theological viewpoints. This publication represents an early attempt to bring together diverse voices on the investigation of a wide variety of religious claims, positions and identities on homosexuality. In many ways, Comstock and Henking's volume demonstrated a broad effort to widen the emerging conversation around methodology in queer theory to be as inclusive as possible in relation to diverse religious traditions and trends.

Although published nearly ten years after his groundbreaking manifesto for gays and lesbians, Goss navigated away from queer apologetics in his 2002 publication Queering Christ, where he challenges Christian heteronormativity and develops a mature theology of LGBT liberation. The following year, Elizabeth Stuart's Gay and Lesbian Theologies: Repetitions with Critical Difference (2003) provided something of a synthetic survey of many previous movements within theology that might be called 'queer', and in doing so, she pointed the way toward a radical reading of Christianity as a faith that called believers to move beyond a focus on gender and sexual identities. Unfortunately, churches, on the whole, still resist such movement.

Gerard Loughlin's collection of essays titled Queer Theology: Rethinking the Western Body (2007) was an explicitly theological project. Although queer thought was already active within theological thought, it was often left to the margins (and still is). Loughlin's volume attempted to address this dislocation by focusing distinctly on demonstrating the relevance of queer thought for theological thought in general. He did this by bringing some of the most visible voices active in queer theology_including Mark D. Jordan, James Alison, Elizabeth Stuart and Eugene F. Rogers - into dialogue with one another. This publication marked something of a defining moment for the theological subfield, as it sought to widen our understanding of theology, and to place queer theology at its center. As Loughlin described matters, 'Theology is a queer thing. It has always been a queer thing'. ${ }^{13} \mathrm{He}$ continued,

$[\ldots]$ even when theology was culturally dominant it was strange, for it sought the strange; it sought to know the unknowable in Christ, the mystery it was called to seek through following Jesus. And of course it has always been in danger of losing this strangeness by pretending that it has comprehended the mystery, that it can name that which is beyond all names. Indeed - and despite its own best schooling - it has often succumbed to this danger, which it names "idolatry". ${ }^{14}$

It was after Loughlin's volume that queer theology, so-called, quickly expanded to become a subfield in its own right, now complete with introductory texts, including Patrick S. Cheng's trilogy of sorts: Radical Love: An Introduction to Queer Theology (2011), From Sin to Amazing Grace: Discovering the Queer Christ (2012) and Rainbow Theology: Bridging Race, Sexuality, and Spirit (2013). Queer Theology even

${ }^{13}$ Loughlin, Gerard. “Introduction.” In Queer Theology edited by Gerard Loughlin. Malden: Blackwell, $2007,7$.

${ }^{14}$ Ibid. 
attracted inclusion in the 'Controversies within Contextual Theology' series at this time, for which Susannah Cornwall produced Controversies in Queer Theology (2011). While acknowledging in her survey of the field that there is no monolithic definition of queer theology, Cornwall does note that the categorization conveys a sense of 'opposition to regulatory normativities', specifically regarding sexuality in this case, but somehow also extending itself beyond this particularity and toward any condition or reality in the material condition of human existence that calls for witness. ${ }^{15}$ Cornwall's understanding of queer theology as that which challenges the very construction of 'normal' within theology is central to the possibility of our volume, which also brings together diverse voices, including voices that self-identify as heterosexual but seek to contribute to the impact queer theory and theology can have on the entire field of theological inquiry.

The inclusion of straight voices in a volume of queer theology may seem to many as a violation of the project of 'queering' theology, since such a voice does not (and cannot) speak out of an existence lived at the margins. In response to such potential objection, we appeal to Cornwall's insistence that

[...] this does not mean that all particularity and specificity need be erased: for queer theologies to advocate amorphousness would indeed be problematic... Nonetheless, by insisting that all identity and all normativity must be queried, queer theologians are deeply egalitarian and deeply apophatic. They do not allow any one ideology or identity to become paramount, but act as a way to interrogate unproblematized resignation to the power of imperfect structures and norms. ${ }^{16}$

It is within such a context that we want to frame this volume's exploration of the queering of theology as a unique manifestation of a contextual theology insofar as we claim that what queer theology perhaps offers us most directly is a model that we can use to understand the essence of what theological practice is, or at least what it should be. We turn now to the ways in which we understand queer theologians pointing toward the essence of what theology might someday become.

The Role of Witness within Queer Theology

One of the essential features of 'doing theology' is simply to provide witness. Over time, theologians have done just this in many different and interesting ways. We would venture so far as to say that queer theology has reawakened a certain awareness among contemporary theologians of the significance of witness as the powerful way we extend the love of Christ simply through sharing 'not only the Gospel, but ourselves as well'. ${ }^{17}$ This is why the sharing of personal stories of self-identified queer persons who have struggled and continue to struggle with their place and identity as Christians has had such a profound effect.

There are numerous examples in queer theology of the transformative power of witness, including substantial work focused specifically on biblical witness. These include the work of Nancy Wilson in her publication Our Tribe: Queer Folks, God, Jesus, and the Bible (1995), Larry Kent Graham's book Discovering Images of God: Narratives of Care among Lesbians and Gays (1997), Take Back the Word: A Queer Reading of the Bible published in 2000 by Robert E. Goss and Mona West, and more recently, Ken Stone's latest installation in the field, Practicing Safer Texts: Food, Sex and Bible in Queer Perspective (2005). ${ }^{18}$

\footnotetext{
${ }^{15}$ Cornwall, Susannah. Controversies in Queer Theology. London: SCM Press, 2011, 38.

${ }^{16}$ Ibid., 67-8.

${ }^{17} 1$ Thessalonians 2:8

${ }^{18}$ Stone previously authored Queer Commentary and the Hebrew Bible (2002) and Sex, Honor, and Power in the Deuteronomist History (1996).
} 
Jeff Chu's series of interviews published as Does Jesus Really Love Me? A Gay Christian's Pilgrimage in Search of God in America (2013) presents another perspective on queer witness. Here Chu attempts to convey various stories about the struggle and insight that he finds among gay Christians in America. In an effort to understand why so much vitriolic energy and hatred has been directed toward queer groups in particular, Chu's journey of witness leads the reader to insight that is significant to the systematic reflection of so many personal narratives, which are often delivered with little commentary. Chu explains that he realized that 'It's almost as if people are speaking entirely different languages. And it's almost as if people are preaching totally different faiths' ${ }^{19}$ And yet, telling these stories of struggle neutrally, without asking audiences to judge them from either pro- or -anti-gay standpoints, does have a cumulative effect of transformation over time. In fact, Chu argues, if enough people simply stop to listen to the stories of their neighbors, coworkers, family members, etc. preconceived notions of marginalized identities can be, and have been, positively transformed.

In his series of journalistic accounts, Chu highlights several major areas for potential reform and invites us, both as people of God and as those who seek to queer theology, to reconsider how we understand even that to which we aim to provide witness. Similar to other works briefly mentioned above, Chu's call to us is also that issues forth for queer theology as a whole: we must seek out and show to the world that which is 'queer' in our churches, in our theologies, even in ourselves, so that the 'norms' upon which structures of oppression and marginalization have been erected can be unveiled and, ultimately, destroyed.

For a more personal witness, queer theology has seen contributions such as Tanya Erzen's Straight to Jesus: Sexual and Christian Conversions in the Ex-Gay Movement (2006), Lynne Gerber's Seeking the Straight and Narrow (2012), Bernadette Barton's Pray the Gay Away: The Extraordinary Lives of Bible Belt Gays (2012) and Heather R. White's 2015 history titled Reforming Protestants and the Rise of Gay Rights. Finally, Jay Emerson Johnson offers what may be considered a theological attentiveness to the genre as a whole in his Peculiar Faith: Queer Theology for Christian Witness (2014).

Within the present collection of essays, Johnson's contribution also suggests a way of witnessing to theology that does not aim to be written down. In his essay 'Divine Detritus: Queer Remainders from Theological Quests', Johnson points out that although 'Queerness admits multiple meanings and strategic postures', it also 'nearly always calls into question... the reliability of... categorizations', which leaves theology proper with a sense of uneasiness ${ }^{20}{ }^{20}$ Here Johnson envisions 'queer' through the words of Althaus-Reid, as that which 'surfaces the seeds within theological discourse for its own undoing. ${ }^{21} \mathrm{He}$ goes on to argue that the destabilizing power of queer theology extends to the very foundation of God. Shaking down the formalities and standard modes of doing theology scholastically, Johnson calls attention to bodily pleasures, everyday activities, and other incidentals of life. He relies on the work of Peter Rollins to explain that 'In every... accident of life, the poet sees something divine, and carefully scales off all that encumbers that divinity, and permits it to be revealed in all its transcendent loveliness. ${ }^{22}$ The debris of the ongoing stripping down of ordinary human tasks leaves behind a detritus, in which Johnson finds a theological richness that can be used to disorient mainstream systematic theology. Weaving in and out of theological fragments, popular children's stories, creative representations of Jesus, and a country-western song, Johnson's poetic jaunt into the detritus leads him to cherish anew the 'queer remainders of theological quests' by understanding that in a queer theology, love, which Christians also refer to as God, is best expressed as vulnerability.

\footnotetext{
${ }^{19}$ Chu, Jeff. Does Jesus Really Love Me?: A Gay Christian's Pilgrimage in Search of God in America. New York: HarperCollins, 2013, 73.

${ }^{20}$ Johnson, Jay Emerson. “Divine Detritus: Queer Remainders from Theological Quests” in Queerying Theology's Object edited by Colby Dickinson, Aimee Light, Kent Britnall, and Meghan Toomey, [insert page number/s].

${ }^{21}$ Ibid., 14.

${ }^{22}$ Ibid., 3.
} 
Disentangling the 'Real' Issues Involved in Reactions to a Queer Presence in the Church

Mary Glasspool, suffragist bishop of Los Angeles in the Episcopal Church, USA, and the first openly lesbian bishop elected in the United States, when contemplating what is really going on with people's reactions to an LGBTQ presence in the Church, puts it this way:

It seems to me that it's a heterosexual analysis to think it's all about sex and not about relationships. But what are we really talking about? We're talking about issues of power and authority. This is a culture where men are dominant over women. There's something so profoundly threatening to men in the idea of two women who can have a relationship without them. And they see gay men as effeminate. The real issue worldwide, underlying the sexuality issue, is the gender issue. This is about control. ${ }^{23}$

This quote highlights the second major theme that surfaced in our review of the literature surrounding queer theology: the necessary analysis of all that goes on within the Church concerning a queer presence that has little to nothing to do with actual queer persons and their spiritual and pastoral needs. The 'real issue', as Glasspool points out, has to do with politics, power and the struggles that typify institutional leadership. These are issues that queer theologians have addressed substantially and must continue to do so.

One of the first explorations of these issues was the sociological analyses presented in Stephen Hunt's edited volume Contemporary Christianity and LGBT Sexualities (2009). Relatedly, Scott Thumma and Edward R. Gray also produced an edited volume, titled Gay Religion (2004), which aims to objectively depict real lived experiences and expressions of spirituality and religious practices of LGBT persons. Gay Religion drew from a wide range of religions, including established religious institutions, different denominations, sects and organizationally non-affiliated spiritual expression.

A more focused analysis is offered by Dawne Moon in God, Sex, and Politics: Homosexuality and Everyday Theologies (2004), where Moon argues that Christians need to focus on becoming increasingly conscious of how the political pervades everything within ecclesial structures. ${ }^{24}$ In so doing, Moon urges her audience not to let this fact stymie their efforts to overcome oppression and marginalization within Christianity: "If we see human society as necessarily "political" then we can recognize, negotiate, and challenge hierarchies of power and privilege. This need not depress us'. ${ }^{25}$ Moon continues by pointing out the unrealistic nature of the typical vision of 'Christian life' as a 'higher calling' to live 'free' from all political and worldly influence. ${ }^{26}$ She argues that such a 'reality' is not only highly improbable, but it also is not something that Christians should desire, because this vision of life transferred to reality inevitably involves the explicit exclusion of some persons. Moon explains: 'The question then is to what extent members - of particular religious groups or the larger society — can find a sense of community and transcendence without denying it to others' ${ }^{27}$

Similarly, Brandy Daniels, in her essay included in this volume, critiques Stanley Hauerwas' vision for a community of character somewhat along these lines. Daniels argues that 'Hauerwas offers a vision of the

${ }^{23}$ Quoted in Chu, Does Jesus Really Love Me?: A Gay Christian's Pilgrimage in Search of God in America, 282

${ }^{24}$ In Moon's view, Christians tend to define 'as "political" those things that threatened to denaturalize their ideals' (Moon, God, Sex, and Politics, 231) - though what exactly qualifies as 'natural' and what does not is not always easy to sort out.

${ }^{25}$ Moon, Dawne. God, Sex, and Politics: Homosexuality and Everyday Theologies. Chicago: University of Chicago Press, 2004, 233.

${ }^{26}$ Ibid., 240.

${ }^{27}$ Ibid., 241. 
formation of (and, concomitantly, by) a community of character - the church - that, counter to his aims, is ultimately unvirtuous because/as it problematically devalues and delimits difference. ${ }^{28}$ She explains that Hauerwas' vision of formation 'undermines, and ultimately oppresses, difference - through assimilation, homogenization, normalization, and/or exclusion. ${ }^{29}$ Daniels uses queer theoretical work on temporality in dialogue with the work of Dietrich Bonhoeffer to reimagine Christian formation that emphasizes the 'middleness' of our human existence and its consequent limitations, and offers non-linear paths which lead to a queer futurity where we are nourished by experiences of ecstasy, encounters with others, and appreciation for diversity and difference.

Theologians doing both black theology and queer theology also highlight ways in which inclusion/exclusion dynamics operate within Christianity, relegating certain persons to the margins of the Church. Gary David Comstock addresses exclusion of lesbians and gay men from the black church in $A$ Whosoever Church: Welcoming Lesbians and Gay Men into African American Congregations (2001). Kelly Brown Douglas took on this same issue from specifically a womanist perspective in her work Sexuality and the Black Church (1999), and most recently Ashon T. Crawley renews these concerns in Blackpentecostal Breath: The Aesthetics of Possibility (2016).

Inspecting the rhetoric, the politics and the myriad ways in which we avoid the 'real issue' will always come back to a choice between whom we exclude and whom we include. Our brief discussion here points to the fact that the Church often plays a major role in whose bodies end up living 'on the margins' of society, a factor that cannot be downplayed, but must be understood. ${ }^{30}$ This insight leads us directly into the next major theme we have identified as central to the essays contained in this volume: creatively rereading Christian tradition in ways that reveal its own general "queerness".

\section{Creatively Rereading Tradition with an Eye toward Emancipation}

In many ways, queer theology got its start by offering creative rereadings of history, providing a solid (and often seemingly 'neutral') foundation of academic scholarship from which queer theologians could build more systematic theological responses within the tradition. Most exemplary in this regard is the work of Mark D. Jordan. Jordan's earlier works, The Invention of Sodomy in Christian Theology (1998) and The Silence of Sodom: Homosexuality in Modern Catholicism (2000) were both historically-based academic studies. Subsequently, Jordan published theological reflections that were more generally systematic in Telling Truths in Church: Scandal, Flesh, and Christian Speech (2004) and Recruiting Young Love: How Christians Talk about Homosexuality (2011).

Such a movement from the recovery of select theological and historical sources to the formation of a more traditional systematic theological reflection can also be seen in Eugene F. Rogers Jr.'s Sexuality and the Christian Body: Their Way into the Triune God (1999). Mentioned already is the work of Catholic theologian James Alison's, who worked his organized theological reflection through many publications, including Faith Beyond Resentment: Fragments Catholic and Gay (2001), On Being Liked (2003), Undergoing God: Dispatches from the Scene of a Break-In (2006) and Broken Hearts and New Creations: Intimations of a Great Reversal (2010). In his work, Alison, who dissents from the Church's teaching on homosexual persons ${ }^{31}$, tries to develop a theology that, in his words, may 'fail' in some sense

\footnotetext{
${ }^{28}$ Daniels, "Chrononormativity and the Community of Character: A Queer Temporal Critique of Hauerwasian Virtue Ethics" in Queerying Theology's Object edited by Colby Dickinson, Aimee Light, Kent Britnall, and Meghan Toomey, [insert page number/s].

${ }^{29}$ Ibid., 3.

${ }^{30}$ See his chapter 'On Receiving and Inheritance: Confessions of a Former Marginaholic' in On Being Liked, New York: The Crossroad Publishing Company, 2004, 65-77.

${ }^{31}$ See, e.g., Alison, Faith Beyond Resentment, 183.
} 
to be systematic. ${ }^{32}$ However, in our perspective, what Alison does is theology pure and simple, even though it is often done in very creative and profound ways.

One of the most important rereadings of tradition is presented too in Kathryn Lofton's closing essay "Everything Queer?" from the collection Queer Christianities: Lived Religion in Transgressive Forms (2014) edited by Kathleen T. Talvacchia, Mark Larrimore and Michael F. Pettinger. Lofton's essay raises a key question for both queer theology and the larger field of Christian theological studies: "What isn't queer about Christianity?" Lofton, and many contributors to this volume in her wake, assert that Christianity itself is (and has been throughout its history) a 'queer' enterprise, one that gives witness to non-normative existence and which contains an inherent function to challenge systems and patterns of power and domination.

Lofton's question resounds at the heart of our project to 'queer' theology, as part of the task of queering theology is to raise up the ways in which, since its inception, Christianity has been grounded in patterns and ways of thinking which expose normativities as superficial and damaging to humans, who, we must not forget, were created to reflect the infinitely diverse nature of the Christian God of love. Since the publication of "Everything Queer", a tendency has developed within queer theology, including within this collection of essays, to collapse 'queer' and 'Christian' together, substantiating the obvious answer to Lofton's rhetorical call to all Christian theologians to acknowledge and uncover the general 'queerness' of our shared vision.

Ironically, identifying ways in which queer theology or queer theologians have relied on either traditional Christian knowledges, theological sources or systematic methodology raises a key question for the future shaping of a field of queer theology: how can queer theology itself keep from becoming, at least in some ways, normative theologically? Identifying and tracing the progression of methods, approaches, themes etc. that queer theologians share in common, is a reflective process that seems precariously close to the work of outlining the shared 'norms' of a field of study.

This volume includes critiques of thinkers who, despite their best efforts, have failed to filter out foundational biases of heteronormativity from their ideas and methodology. In his essay herein, J. Leavitt Pearl builds a vision of queering phenomenological theology from a critique of Jean-Luc Marion's phenomenology, which he argues fails to transcend heteronormative ideology. Pearl states: 'While many of [Marion's] insights might offer new openings for theological thought, his phenomenological speculations nonetheless often merely serve to re-inscribe a traditional, even reactionary heteronormativity into the heart of postmodern theological thought. ${ }^{33}$ Relying on the work of Sara Ahmed, Pearl proposes that in order to queer phenomenological theology, foundational presuppositions and methodologies must be rethought. Pearl suggests that to succeed in such a project, theologians must vigilantly seek 'queer moments', which are moments that serve to interrupt theology-as-usual, rupturing normative ideas and bodies with queerness.

Pearl, like many other queer theologians, suggests a project of ongoing denormitivization. This again raises the question that is key to the future of queer theology, especially as it continues to systematically catalog and organize itself: how accepted should we want queer theology to be? Stated differently, can queer theology move from the margins of theological inquiry to the center without losing its critical edge? And, further, is this something queer theologians should induce or resist? Our own contributors to this

\footnotetext{
${ }^{32}$ See, e.g., his comment on his own work in Alison, On Being Liked, 101

${ }^{33}$ Pearl, J. Leavitt. "Jean-Luc Marion: The Reinscription of Heteronormativity into Postmodern Theology" in Queerying Theology's Object edited by Colby Dickinson, Aimee Light, Kent Britnall, and Meghan Toomey, [insert page number/s].
} 
volume, following in the footsteps of the many courageous and groundbreaking theologians who have come before, suggest an answer: we must continue to point theology toward what really matters.

\section{Pointing Theology towards What Really Matters}

Jeff Chu describes 'the Church' as '[...] an institution that has shown itself to be incapable of dealing with who we are and where we are - and a church that is ill-equipped for honesty is not a church worthy of the Jesus of the Bible'. ${ }^{34}$ A damning charge indeed, but perhaps a fitting one as well. Many persons throughout history have been denied a certain fullness of human expression because they were rendered silent by an institution, or its agents, that failed in its divine mandate to embody the unconditional love of Jesus Christ. The legacy such silencing leaves to contemporary Christians can only be discerned with speculation at best. With so many of its members being kept from bringing their deepest desires to the light of day, we can only assume that silence has had a great impact in shaping the Church into what it is today.

In her contribution to the present collection, Kristen Justaert encourages a reinvigoration of queer religious agency within Christianity, by investigating forms of community life that can contribute to queering theology. Relying on examples from Christian history of communities who lived an 'alternative life', a 'vita apostolica', such as the $13^{\text {th }}$ Century Beguines in the Low Countries, Justaert addresses her concern that 'Within the context of neoliberal capitalism, Queer Theology seems to have lost its queerness' ${ }^{35}$ Affirming the important critical stance that queer theology has always taken against not only heteronormativity, but also colonialism and capitalism, Justaert looks to strengthen collective queer religious agency by seeking out and embracing the 'poverty of queerness'. She suggests that queering theology is a spiritual, as well as an academic and political task. Further, she points out, in chorus with many others who participate in these tasks, that queering theology is about a deeply spiritual desire, not just a sexual one.

Throughout this project, we have continually contemplated the way in which queer theology functions to disrupt and challenge the often monolithic narratives of 'theology' proper. Perhaps no theologian has captured this tension better than the late Marcella Althaus-Reid, to whom many of our authors refer. Althaus-Reid framed this disruptive function as a task of Indecent Theology: Theological Perversions in Sex, Gender and Politics (2000), of looking for The Queer God (2003) and, therefore, of making the journey From Feminist Theology to Indecent Theology (2004). Althaus-Reid's focus in these publications and others centered on the real, and much needed, poverty of faith. She utilized a variety of examples, including the 'unusualness' of certain Christians who are poor and who deviate from the sexual norms of a given society, especially those gestures of 'decentralization' seen as 'indecent' to many. ${ }^{36}$

This unusualness is the condition of their indecency, that is, of the subversion of sexual and gender codes in their lives as a result of their struggle for life and dignity. I know, because once I was one of them, a poor woman on the streets of Buenos Aires and I am indecent enough to be able to reflect with theological honesty on issues of women, economic struggle, images of God and the flow of sexual desires. ${ }^{37}$

Never shying away from the goal of rendering theology non-normative in ways that give life to marginalized persons, Althaus-Reid sought to embody a 'critical continuation of Feminist Liberation

\footnotetext{
${ }^{34}$ Chu, Does Jesus Really Love Me?, 342.

35 Justaert, Kristen. “The Power of Poverty: Queer Religious Agency Past \& Present” in Queerying Theology's Object edited by Colby Dickinson, Aimee Light, Kent Britnall, and Meghan Toomey, [insert page number/s].

${ }^{36}$ Althaus-Reid, Marcella. Indecent Theology: Theological Perversions in Sex, Gender and Politics. London: Routledge 2000, 168.

${ }^{37}$ Ibid., 5 .
} 
Theology', one that seeks not to reify or fetishize the poor, but to descend into their everyday lives and to embrace the complexity that emerges from this place. ${ }^{38}$ She simply called things as they were:

The problem is that it is easier to live without God than without the heterosexual concept of man. They need to be undressed simultaneously. The subversiveness of a religious system lies in its sexual subversions, in that disorderly core of abnormal sexual narratives where virgins give birth and male trinities may signify the incoherence of one male definition only, in the tension between patriarchal identity and difference. ${ }^{39}$

The goals of no longer being '(hetero)sexual neutral theologians' ${ }^{40}$ and of even 'sexually deconstructing' Christ ${ }^{41}$ were paramount to her, and tasks that all theologians should take up in their work. It would not be 'systematic' or even 'neat', as 'An Indecent Theology will always come from the margins of imprecision and mismatches' ${ }^{42}$ Hence, promoting a utopian, irruptive desire that cannot be domesticated ${ }^{43}$, AlthausReid explored new possibilities for theological interventions in our world while simultaneously taking up the call to 'challenge precisely the unnaturality and abnormality of the present sexual ideology'. ${ }^{44}$

Echoing Moon's call to embrace the political at the same time as we seek inclusion into the community of believers, Althaus-Reid implores us to go out ' $[. .$.$] from that dialectic of decency/indecency in our lives$ [and] think politics and theology at the same time'. ${ }^{45}$

\section{Conclusion}

Wendy Farley describes the state of theology today as such:

For all of its brilliance and variety, mainstream theology has rarely extended its full reach. It has not been able to stretch fully into the awareness of the Divine Eros as the foundation of all reality, within which Christians are only the tiniest drop. It cannot embrace the random, chaotic, amoral beauty of the cosmos, irreducible to our needs or our ordering. It violates the universal implications of the commandment to love by envisioning humanity split into sinners and saved. It cannot translate divine mercy into humility about our small efforts toward understanding. ${ }^{46}$

We can only echo Farley's description, and at the same time offer something like a vision of a future direction for the queering of theology, as our own attempt to orient ourselves toward what really matters. We believe something like the movements that a possible queer theology promotes has the potential to forge a path ahead that can lead the whole field of theology in pursuit to more fully honor its own integrity, and to more robustly embody that which is the ground of all that exists. Such a path mandates us to seek out the 'poverty of theology' and to acknowledge it as what it is: a failure. The poverty of theology represents our failure as a field to achieve 'success' in 'systematic' rigor or monolithic consistency. However, we must begin to understand this as a wonderful, even a wondrous, form of failure. This is not a failure that imitates or succumbs to the typical 'failures' associated with the establishment of social identity.

\footnotetext{
${ }^{38}$ Ibid., 7, 34.

${ }^{39}$ Ibid., 18.

${ }^{40}$ Ibid., 19.

${ }^{41}$ Ibid., 95.

42 Ibid., 64.

${ }^{43}$ Ibid., 72.

${ }^{44}$ Ibid., 131.

45 Ibid., 179.

${ }^{46}$ Farley, Wendy. Gathering Those Driven Away: A Theology of Incarnation. Louisville: Westminster John Knox Press, 2011, 7.
} 
In this sense, insecurities about one's personal identity should be listened to, taken seriously, and embraced as something that should never really go away. Such feelings and thoughts can reveal what parts of one's self are not 'satisfied' by the imposed normative accounts of socially-constructed dualistic roles, such as 'being male' or 'being female', or 'being straight' or 'being gay'. Perhaps personal insecurities are actually important and inspired locations for God's self-revelation. Understanding this helps us to appreciate why we must be particularly attentive to groups and individuals who choose to live a 'non-normative' lifestyle (such as gay partnerships that refuse to marry despite the civil right to do so), for these groups and individuals may also contain something of divine inspiration to reflect. Certainly, locations of non-normativity have important lessons to teach us about what is actually intended (and effected) by societal and religious structures of normativity.

As such, we suggest that theology could benefit greatly from overturning, inverting or otherwise shaking up our typical modes of inquiry. We need to ask difficult, rarely considered, questions about the 'normative' accounts we give for identity. We must take up, again and again, in evermore depth and humility, the real issue of power relations, and the consequent problems of fear, poverty and silence. We must examine the inability of certain 'normative' persons (some of ourselves included) to imagine living otherwise than within the structures of privilege they currently occupy and from which they benefit at a cost to others. This goes far beyond sexuality, into economic divisions, struggles of gender, race, and disability, as well as many other marginalized aspects of personhood. Throughout our inquiries, it is imperative to recall that structures of power are always rooted in these same manifestations of personhood, the ever so precarious particularities of our existence. As such, we can only know and react to power dynamics through these embodied traits and identities. Therefore, our very embodiment of the characteristics of personhood, such as gender, race, sexuality etc., speak directly to the heart of the issue. Following such lines of inquiry can open us up to new, even occasionally unthought, ways to more authentically embody our own existence.

Theology must go to this field of relations and study their economies of representation anew. At the same time, we must look to promote the fullness of the human being in relation to that which goes far beyond whatever normative structures have been given to us - and often erroneously and irreverently justified by misuse of the Christian God. Indeed, God, whatever God's being is made of, is something wholly beyond whatever structures we see around us in the world. Although, this may not be an adequate reason to simply abandon these structures, it is neither a reason to proceed as if everything religious were descended directly from the hand of God. Theology must always contain within itself a source for a 'pure critique' of itself, and it is in this way that the continuing project of 'queering' theology can find its atypical sense of failure, or poverty, which is at the beginning of the path we envision for the future of queer theology.

This makes all theology, in some sense, an inherently 'queer' undertaking, as Lofton suggested. To 'queer' theology is to take that which makes up the concept, the noun, 'queer' and apply it to theology. It is a theology that aims to erase boundaries, its own and others'. It is a theology that uncovers new ways of understanding things by allowing hidden voices and hidden perspectives to come into the light. Queering theology means developing a methodology that incorporates transgressive actions, and opposes social, cultural and even religious norms. To queer theology, then, is to take up a posture of resistance, an attitude of questioning, and an intellect informed by deconstruction. When we place the word 'queer' before the word 'theology', the result is a call, it is a path to follow, not a normative field of study. A theology that is queer calls us to go beyond what is known, to move past what is established, and to relinquish control over such structures totally.

This is why queering theology must be the heart of any legitimate theological endeavor. The infinitely diverse God of love and mercy calls us to interrogate and upend the presumptions, normative structures and identities that we inherited from the ever-elusive, constantly evolving 'system' of power that 
overshadows our existence. There is no better place of doing theology than in the face of manifestations of this power, for this must be the most fecund locus for encountering revelation of the divine. 